\title{
Index to Volume 37, 2021
}

\author{
Contents of Volume 37, Numbers 1-4 \\ Articles, see Author Index \\ Book Review 1079 \\ Editorial Collaborators 1083 \\ Index 1091 \\ Letter to the Editors 543 \\ Preface 257, 533
}

\begin{abstract}
Author Index
Alleva, G., Falorsi, P.D., Petrarca, F., and Righi, P. Measuring the Accuracy

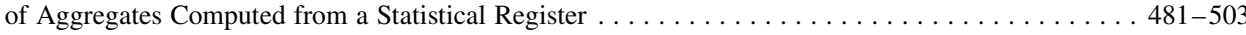

Alvarado-Leiton, F., See Boonstra, P.S.

Andridge, R.R., See Boonstra, P.S.

Arora, S.K., Kelley, S., and Madhavan, S. Building a Sample Frame of SMEs

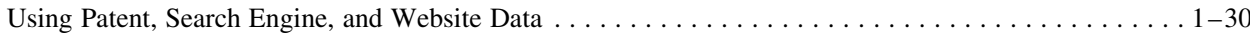

Bach, R., See Eckman, S.

Bach. R., See Haas, G.-C.

Bacchini, F., Baldazzi, B., De Carli, R., Di Biagio, L., Savioli, M., Sorvillo, M.P., and Tinto, A. The Evolution of the Italian Framework to Measure Well-Being . . . . . . . . . . . . . 317-339

Baffour, B., Brown, J.J., and Smith, P.W.F. Latent Class Analysis for Estimating

an Unknown Population Size - with Application to Censuses. . . . . . . . . . . . . . . . . . . . . . . . . . . 673-697

Bakker, B.F.M., See Zult. D.

Baldacci, E., See Di Iorio, F.

Baldazzi, B., See Bacchini, F.

Beenstock, M. and Felsenstein, D. Freedom of Information and Personal

Confidentiality in Spatial COVID-19 Data . . . . . . . . . . . . . . . . . . . . . . . . . . . . . 791-809

Bhattacharjee, A., See Zhang, Z.

Bijak, J., Bryant, J., Gołata, E., and Smallwood, S. Preface . . . . . . . . . . . . . . . . . . . . . . . . . . 533-541

Bison, I., See Zeni, M.

Boonstra, P.S., Little, R.J.A., West, B.T., Andridge, R.R., and Alvarado-Leiton, F.

A Simulation Study of Diagnostics for Selection Bias . . . . . . . . . . . . . . . . . . . 751-769

Bottone, M., Modugno, L., and Neri. A. Response Burden and Data Quality

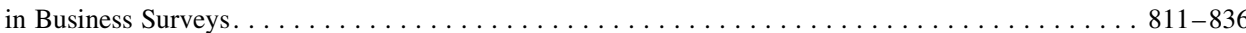

Brown, J.J., See Baffour, B.

Bryant, J., See Bijak, J.

Büttner, T.J.M., Sakshaug, J.W., and Vicari, B. Evaluating the Utility of Linked

Administrative Data for Nonresponse Bias Adjustment in a Piggyback Longitudinal

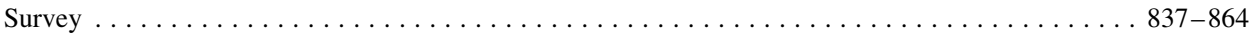

Buono, D., See Di Iorio, F.

Calderwood, L., See Peycheva, D.N.

Carausu, F., See Mazzi, G.L.

Chessa, A.G. A Product Match Adjusted R Squared Method for Defining Products with Transaction Data . . . . . . . . . . . . . . . . . . . . . . . . . . . . . . . . 4 411-432

Corona, F., Guerrero, V.M., and Lœpez-Peréz, J. Optimal Reconciliation of Seasonally

Adjusted Disaggregates Taking Into Account the Difference Between Direct and

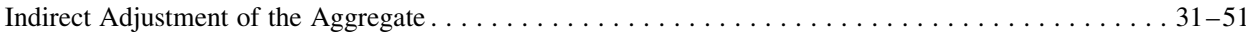


Cristancho, C., See Fúquene-Patiño, J.

Daalmans, J., See Scholtus, S.

Daddi, S., See Righi, P.

De Carli, R., See Bacchini, F.

De Vitiis, C., Guandalini, A., Inglese, F., and Terribili, M.D. Assessing and

Adjusting Bias Due to Mixed-Mode in Aspect of Daily Life Survey . . . . . . . . . . . . . . . . . . . . 461-480

De Wolf, P-.P., See Zult. D.

Di Biagio, L., See Bacchini, F.

Di Gennaro Splendore, L., See Di Iorio, F.

Di Iorio, F., Baldacci, E. Buono, D., Di Gennaro Splendore, L., Elliott, D.,

Killick, R., Laureti, T., Pratesi, M., and Shlomo, N.

Dodd, E., See Hilton, J. Preface .

Eckman, S., and Bach, R. Panel Conditioning in the U.S. Consumer Expenditure

Survey . . . . . . . . . . . . . . . . . . . . . . . . . . . . . . . . . . . 53-69

Eckman, S., See Haas, G.-C.

Elliott, D. See Di Iorio, F.

Elliott, M.R., and Xia, X. Weighted Dirichlet Process Mixture Models to

Accommodate Complex Sample Designs for Linear and Quantile Regression. . . . . . . . . . . . . . 71-95

Fabi, C., See, Mingione, M.

Falorsi, P.D., See Alleva, G.

Falorsi, P.D., See Righi, P.

Félix-Medina, M.H. Combining Cluster Sampling and Link-Tracing Sampling

to Estimate Totals and Means of Hidden Populations in Presence of Heterogeneous

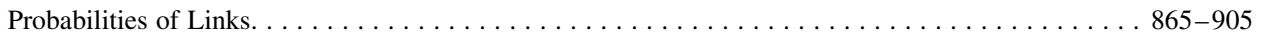

Felsenstein. D., See Beenstock, M.

Fiorello, E., See Righi, P.

Folkman Gleditsch, R., Syse, A., and Thomas, M.J. Fertility Projections in a

European Context: A Survey of Current Practices among Statistical Agencies . . . . . . . . . . . . . 547-568

Forster, J.J., See Hilton, J.

Fúquene-Patiño, J., Cristancho, C., Ospina, M., and Morales Gonzalez, D.

Fay-Herriot Model-Based Prediction Alternatives for Estimating Households

with Emigrated Members. . . . . . . . . . . . . . . . . . . . . . . . . . . . . . . . . 771-789

Gauckler, B., See Zeni, M.

Giunchiglia, F., See Zeni, M.

Gołata, E., See Bijak, J.

Goujon, A., See Wazir, A.

Graubard, B.I., See Xu, M.

Guandalini, A., See De Vitiis, C.

Guerrero, V.M., See Corona, F.

Heumann, C., See Razzak, H.

Hilton, J., Dodd, E., Forster, J.J., and Smith, P.W.F. Modelling Frontier

Mortality Using Bayesian Generalised Additive Models . . . . . . . . . . . . . . . . . . . . . . . . . . .569-589

Haas, G.-C., Eckman, S., and Bach, R. Comparing the Response Burden between

Paper and Web Modes in Establishment Surveys . . . . . . . . . . . . . . . . . . . . . . . 907-930

Inglese, F., See De Vitiis, C.

Jin, J., and Loosveldt, G. Identifying Outliers in Response Quality Assessment

by Using Multivariate Control Charts Based on Kernel Density Estimation

Kelley, S., See Aurora, S.K.

Killick, R., See Di Iorio, F.

Kitchin, R., and Stehle, S. Can Smart City Data be Used to Create New

Official Statistics? .

Kohaut, S., See König, C.

König, C., Sakshaug, J.W., Stegmaier, J., and Kohaut, S. Trends in

Establishment Survey Nonresponse Rates and Nonresponse Bias: Evidence from

the 2001-2017 IAB Establishment Panel.

Landsman, V., See Xu, M.

Lanzieri, G. Letter to the Editors: International Comparability of Population

Statistics is Essential 
Laureti, T., See Di Iorio, F.

Lasinio, G.J., See Mingione, M.

Little, R.J.A., See Boonstra, P.S.

Lok, R., See Van den Brakel, M.

Loosveldt, G., See Jin, J.

Lœpez-Peréz, J., See Corona, F.

Lugtig, P., See McCool, D.

Madhavan, S., See Aurora, S.K.

Maiti, T., See Zhang, Z.

Marchetti, S., and Tzavidis, N. Robust Estimation of the Theil Index and the

Gini Coeffient for Small Areas. . . . . . . . . . . . . . . . . . . . . . . . . . . . . . . . . . . . 955-979

Marques, J., See Zhang, Z.

Massoli, P., See Righi, P.

Máténé Bella, K., and Ritzlné Kazimir, I. A Structural Equation Model for

Measuring Relative Development of Hungarian Counties in the Years 1994-2016. . . . . . . . . . 261-287

Mazzi, G.L., Mitchell, J., and Carausu, F. Measuring and Communicating the

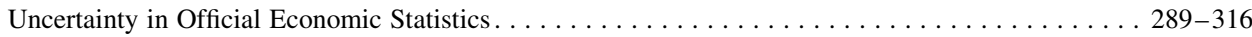

McCool, D., Lugtig, P., Mussmann, O., and Schouten, B. An App-Assisted

Travel Survey in Official Statistics: Possibilities and Challenges . . . . . . . . . . . . . . . . . . . 149-170

McElroy, T. A Diagnostic for Seasonality Based Upon Polynomial Roots

of ARMA Models . . . . . . . . . . . . . . . . . . . . . . . . . . . . . . . . . . . . . . . . . . . . . . . 367-394

Mingione, M., Fabi, C., and Lasinio, G.J. Measuring and Modeling Food Losses . . . . . . . . . . . . 171-211

Michiels, J., See Van den Brakel, J.

Mitchell, J., See Mazzi, G.L.

Modugno, L., See Bottone, M.

Morales Gonzalez, D., See Fúquene-Patiño, J.

Mussmann, O, See McCool, D.

Neri. A., See Bottone, M.

Neumayr, J., See Schork, J.

Ospina, M., See Fúquene-Patiño, J.

Petrarca, F., See Alleva, G.

Peycheva, D.N., Sakshaug, J.W., and Calderwood, L. Occupation Coding During

the Interview in a Web-First Sequential Mixed-Mode Survey . . . . . . . . . . . . . . . . . . 981-1007

Pratesi, M., See Di Iorio, F.

Raftery, A.E., See Ŝevĉíková, H.

Razzak, H., and Heumann, C. A Hybrid Technique for the Multiple Imputation

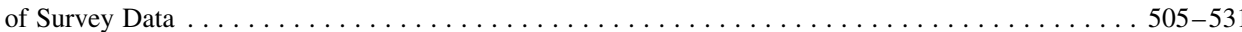

Reis, F., See Zeni, M.

Righi, P., See Alleva, G.

Righi, P., Falorsi, P.D., Daddi, S., Fiorello, E., Massoli, P., and Terribili,

M.D. Optimal Sampling for the Population Coverage Survey of the New Italian

Register Based Census. . . . . . . . . . . . . . . . . . . . . . . . . . . . . . . . . . . 655-671

Riillo, C.A.F., See Schork, J.

Ritzlné Kazimir, I., See Máténé Bella, K.

Roberson, A. Applying Machine Learning for Automatic Product Categorization . . . . . . . . . . . 395-410

Sakshaug, J.W., See Büttner, T.J.M.

Sakshaug, J.W., See König, C.

Sakshaug, J.W., See Peycheva, D.N.

Savioli, M., See Bacchini, F.

Scholtus, S., and Daalmans, J. Variance Estimation after Mass Imputation Based

on Combined Administrative and Survey Data . . . . . . . . . . . . . . . . . . . . . 433-459

Schork, J., Riillo, C.A.F., and Neumayr, J. Survey Mode Effects on Objective

and Subjective Questions: Evidence from the Labour Force Survey . . . . . . . . . . . . . . . . . 213-237

Schouten, B., See McCool,D.

Ŝevĉíková, H., and Raftery, A.E. Probabilistic Projection of Subnational Life

Expectancy . . . . . . . . . . . . . . . . . . . . . . . . . . . . . . . . 591-610 
Shlomo, N., See Di Iorio, F. Smallwood, S., See Bijak, J.

Smith, P.W.F., See Hilton, J.

Smith, P.W.F., See Baffour, B.

Stehle, S., See Kitchin, R.

Stegmaier, J., See König, C.

Sorvillo, M.P., See Bacchini, F.

Syse, A., See Folkman Gleditsch, R.

Terribili, M.D., See De Vitiis, C.

Terribili, M.D., See Righi, P.

Thomas, M.J., See Folkman Gleditsch, R.

Tinto, A., See Bacchini, F.

Tzavidis, N., See Marchetti, S.

Van den Brakel, J. and Michiels, J. Nowcasting Register Labour Force Participation

Rates in Municipal Districts Using Survey Data

1009-1045

Van den Brakel, M. and Lok, R. The Robin Hood Index Adjusted for Negatives

and Equivalised Incomes . . . . . . . . . . . . . . . . . . . . . . . . . . . . . . . . . 1047-1058

Van der Heijden, P., See Zult, D.

Vicari. B., See Büttner, T.J.M.

Wazir, A., and Goujon, A. Exploratory Assessment of the Census of Pakistan Using

Demographic Analysis.

$719-750$

West, B.T., See Boonstra, P.S.

Xia, X., See Elliott, M.R.

$\mathrm{Xu}, \mathrm{M}$., Landsman, V., and Graubard, B.I. Estimation of Domain Means from Business

Surveys in the Presence of Stratum Jumpers and Nonresponse . . . . . . . . . . . . . . . . . . 1059-1078

Zeni, M., Bison, I., Reis, F., Gauckler, B., and Giunchiglia, F. Improving Time Use

Measurement with Personal Big Data Collection - The Experience of the European

Big Data Hackathon $2019 \ldots \ldots \ldots \ldots \ldots \ldots \ldots$. . . . . . . . . . . . . . . . . . . . . 341-365

Zhang, L.-C. Generalised Regression Estimation Given Imperfectly Matched

Auxiliary Data.

Zhang, Z., Bhattacharjee, A., Marques, J., and Maiti, T. Spatio-Temporal Patterns

in Portuguese Regional Fertility Rates: A Bayesian Approach for Spatial

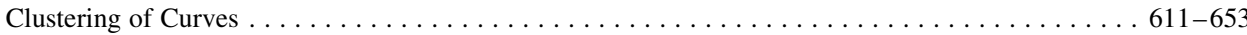

Zult, D., De Wolf, P-.P., Bakker, B.F.M., and Van der Heijden, P. A General Framework

for Multiple-Recapture Estimation that Incorporates Linkage Error Correction

$699-718$

\section{Book Reviews}

Matei, A. Sampling and Estimation from Finite Populations

$1079-1081$ 